\title{
Coupling Compost from Chicken Manure and Inorganic Fertilizer to Improve Cassava (Manihot esculenta Crantz) Growth and Yield on a Ferralitic Soil in Côte d'Ivoire
}

\author{
Kouakou M. Konan ${ }^{1, a}$, Sifolo S. Coulibaly ${ }^{2, b, *}$, Kouadio I. Kouassi ${ }^{3, c}$, Bi Irié A. Zoro ${ }^{1, d}$, Dénezon O. Dogbo ${ }^{1, e}$ \\ ${ }^{I}$ Department of Natural Sciences, Plant Production Research Unit, University Nangui Abrogoua, 02 PB 801 Abidjan 02, Côte d'Ivoire \\ ${ }^{2}$ Department of Biological Sciences, University "Peleforo Gon Coulibaly", BP 1328 Korhogo, Côte d'Ivoire \\ ${ }^{3}$ Department of Natural Sciences, Ecology and Biodiversity Research Unit, University Nangui Abrogoua, 02 BP 801 Abidjan 02, Côte d'Ivoire \\ *Corresponding author
}

\begin{tabular}{|c|c|}
\hline A R T I C L E I N F O & A B S T R A C T \\
\hline $\begin{array}{l}\text { Received : 04/01/2020 } \\
\text { Accepted : } 31 / 03 / 2020\end{array}$ & $\begin{array}{l}\text { This study aimed to evaluate the effect of compost from chicken manure, NPK fertilizer and the } \\
\text { mixture of both fertilizers on agronomic parameters of four varieties of cassava (Yacé, Bonoua, Six } \\
\text { mois and Alleda agba) in Côte d'Ivoire. The field experiment was carried out under a randomized } \\
\text { complete block design with three replicates on a ferralitic soil during two season-cycles. The results } \\
\text { showed that the different fertilizers stimulated plants growth and tuberous roots production. The } \\
\text { highest number of stems (3) and leaves (66) was obtained with the mixture of NPK and compost } \\
\text { applied on the variety "Bonoua". All varieties that received the compost mixed with NPK produced } \\
\text { more leaves with a dominance of the Bonoua variety ( } 65.57) \text {. The highest number of tuberous roots } \\
(5.58) \text {, the heaviest weight per root ( } 6.13 \mathrm{~kg}) \text { and the highest yield ( } 61.37 \mathrm{t} / \mathrm{ha}) \text { were obtained while } \\
\text { using the mixture of compost and NPK as fertilizer and "Bonoua" as variety. Thus, mixing compost } \\
\text { from chicken manure and NPK can be recommended to improve cassava productivity in Côte d'Ivoire } \\
\text { on a ferralitic soil. }\end{array}$ \\
\hline
\end{tabular}

Inorganic fertilizer

Cassava

Côte d'Ivoire

\section{Introduction}

Cassava (Manihot esculenta Crantz) is a plant originated from the Amazon region of Brasil. It has been introduced in West Africa by Portuguese navigators during the $16^{\text {th }}$ century (Jones, 1959). Cassava is one of the most important food crops grown in Africa and is a valuable source of cheap calories in developing countries (Nnadozie and Anumihe, 2003). Apart from its use as food, cassava is also an important industrial raw material for the production of starch, alcohol, pharmaceuticals, gums, confectioneries and livestock feed (Nnodu et al., 2006). Leaves and tender shoots are consumed as vegetables in different parts of Africa (Eke-Okoro and Dixon, 2000).

The total world use of cassava is expected to reach 273 million tons in 2020 (Scott et al., 2000). A higher prediction of demand and production growth estimates the 2020 production at 291 million tons (Scott et al., 2000). In both projections, cassava use in Africa is equivalent to 62 $\%$ of total world production. The production of cassava in West Africa is 155398 million tons, accounting for $55.74 \%$ of the world global production (FAO, 2017). This is justified by the geographic situation of Nigeria, the world biggest producer of cassava. With 4548 million tons per year, Côte d'Ivoire is the $13^{\text {rd }}$ producer in Africa (FAO, 2017). However, cassava plays a crucial role in contributing to food and nutritional security, income generation, poverty alleviation and socio-economic growth in Côte d'Ivoire (N'zué et al., 2013). 
In these recent years, cassava has attained the status of an industrial crop in Côte d'Ivoire. It is now being grown on large scale, repeatedly season after season on the same piece of land. In order to improve cassava production and access to planting material, four new high-yielding varieties of cassava (Yacé, Six mois, Alleda agba and Bonoua) developed through research have been made available to cassava producers. These varieties are resistant to disease and pests and can produce up to 40 tons per hectare per year, compared to less than 20 tons per hectare for traditional cassava varieties (N'zué et al., 2013). Despite the introduction of these improved varieties, the yield of cassava varies between 20 and 30 tons per hectare which is still far below the potential yield. According to Ojeniyi et al. (2009), cassava production is limited by soil fertility status in tropical areas and therefore necessitates application of fertilizers. Cassava removes about $55 \mathrm{~kg}$ of N/ha, $132 \mathrm{~kg}$ of $\mathrm{P} / \mathrm{ha}$ and $112 \mathrm{~kg}$ of $\mathrm{K} /$ ha from soil per cycle (Howeler, 1991). However, farmers rarely use chemical fertilizers due to scarcity and cost, hence the dependence on cheap organic sources of nutrients. These reasons necessitate research on increasing effectiveness of organic manures and suitable rate of application.

Natsheh and Mousa (2014) found that compost application is the best management for increasing soil fertility, cucumber yield and decrease the cost of $\mathrm{N}$ mineral fertilizers. According to Ehab and Ahmed (2015), compost improves Lagenaria siceraria yield. It contains organic matter and nutrients that enhance plant growth and biological substances inhibiting diseases pathogens action (Liu et al., 2013; Catello et al., 2014). Recently, Coulibaly et al. (2019) showed the importance of compost in increasing maize yield and its attributes in Côte d'Ivoire. Despite a lot of works on compost efficacy on numerous plants productivity increase, the performance of compost from poultry manure and its suitable application rate on cassava has not received adequate research attention especially on ferralitic soil in Southern Côte d'Ivoire where cassava is dominant. This work is a comparative study of the effects of NPK fertilizer, compost from poultry manure and combined application of their reduced rates on growth, yield parameters of cassava on ferralitic soil in Southern Côte d'Ivoire.

\section{Materials and methods}

\section{Study Site}

The experiments were carried out at the ecological station of Lamto. The station is situated in the center of Côte d'Ivoire at the southern tip of the "V-Boualé" between latitudes $6^{\circ} 13-6^{\circ} 25$ North and longitudes $4^{\circ} 97$ $5^{\circ} 02$ West. The big rainy season extends from April to July (4 months) and the short rainy season lasts two months (October and November). The big dry season covers 4 months (December to March) and the short dry season lasts two months (August and September) (Durand and Skubich, 1982). The mean temperature varies around $26.49^{\circ} \mathrm{C}$. The mean maximum precipitation is observed in June ( 330.25 $\mathrm{mm})$ and the minimum value in January $(15.47 \mathrm{~mm})$. The relative humidity is higher in September (91.94\%) and lower in April $(85.41 \%)$. The soil of the experimental station of Lamto is ferralitic (ferralsol) (Yao-Kouamé and Allou, 2008).

\section{Plant and Organic Material}

The plant material was composed of healthy stems of four varieties of cassava (Yacé, Six mois, Alleda agba and Bonoua) aged of six months. The plant material was obtained from the "National Center for Agricultural Research (CNRA) in Côte d'Ivoire. All these varieties have a crop cycle of 12 months. The varieties "Yacé" and "Alleda agba" have an erect stem. As for the "Six mois" variety, it has a branching and dichotomous appearance. The "Bonoua" variety has two branches and therefore has a trichotomous appearance. The cuttings were made with pruning shears and the soft parts of the stem were avoided (Raffaillac, 1992). The cuttings had a length of 20 to $25 \mathrm{~cm}$ and had four to six nodes where the axillary buds are located. The planting was done in April and three type of fertilizers (inorganic fertilizer NPK 12-22-22, compost and the mixture of both fertilizers) were applied in May around the cassava plants. NPK 12-22-22 was spread at a rate of $400 \mathrm{~kg}$. ha- ${ }^{-1}$ i.e. $48 \mathrm{~kg} \mathrm{~N} \mathrm{ha}^{-1}, 88 \mathrm{~kg} \mathrm{P}_{2} \mathrm{O}_{5} \mathrm{ha}^{-1}$ and $88 \mathrm{~kg}$ $\mathrm{K}_{2} \mathrm{O} \mathrm{ha}^{-1}$. Compost was applied at a rate of 10 t.ha' ${ }^{-1}$ i.e. $16.8 \mathrm{~g} \mathrm{~N} \mathrm{~kg}^{-1}$, P: $12.6 \mathrm{~g} \mathrm{P}_{2} \mathrm{O}_{5} \mathrm{~g} \mathrm{~kg}^{-1}, \mathrm{~K}: 22.76 \mathrm{~g} \mathrm{~K}^{2} \mathrm{O} \mathrm{kg}^{-1}$. The mixture was composed of $200 \mathrm{~kg}$ of NPK and 5 tons of compost, thus containing $24.08 \mathrm{~kg} \mathrm{~N} \mathrm{ha}^{-1}, 44.06 \mathrm{~kg}$ $\mathrm{P} 2 \mathrm{O} 5 \mathrm{ha}^{-1}$ and $44.11 \mathrm{~kg} \mathrm{~K} 2 \mathrm{O} \mathrm{ha}$. These amounts of fertilizers used were applied at a single dose according to Toukourou and Carsky (2001) and Adjanohoun (2006).

\section{Compost Preparation}

For the preparation of chicken manure compost, a pit (1 $\mathrm{m} \times 1 \mathrm{~m} \times 1 \mathrm{~m})$ was dug and the bottom was cemented to prevent the loss of nutrients. The chicken manure was collected from a farm around the study site. The pit was filled with 50 kilograms of chicken manure and the compost was prepared according to "Indore Indian method" (FAO, 1980). The humidity level in the pit was also regularly adjusted between $50-60 \%$, and then the pit was covered with palm leaves to maintain the humidity.

\section{Experimental Design}

The experimental design was a completely randomized block with three replicates. Each block $\left(320 \mathrm{~m}^{2}\right)$, with 16 elementary plots of $12 \mathrm{~m}^{2}$, corresponded to a type of treatment (NPK, compost, mixture of compost and NPK and control). The consecutive elementary plots were separated by an alley of $2 \mathrm{~m}$ wide and regularly weeded. An elementary plot consisted of three lines of 4 plants, either a total of 12 plants of cassava. Planting was carried out on the same day for all treatments with one cutting per hole at a depth of 2 to $3 \mathrm{~cm}$. The distance between the planting points was $1 \mathrm{~m} \times 1 \mathrm{~m}$, or 10,000 plants ha ${ }^{-1}$. The different elementary plots received a single rate either NPK fertilizer $\left(400 \mathrm{~kg} \cdot \mathrm{ha}^{-1}\right)$, compost $\left(10 \mathrm{t}^{\mathrm{h}} \mathrm{ha}^{-1}\right)$ or the mixture NPK (200 kg)-compost (5 t). All applications were made as surface fertilizer around the cassava plants. Three replicates of the experiment were carried out during two consecutive crops cycle. The first rehearsal was conducted from March 2016 to January 2017 and the second from March 2017 to January 2018. The total rainfall of the two growing periods was $870.90 \mathrm{~mm}$ and $991.70 \mathrm{~mm}$ respectively.

Before the experiment, the soil and the compost were analyzed for $\mathrm{pH}$, total organic carbon (TOC), total $\mathrm{N}$, total $\mathrm{K}$, total available $\mathrm{P}$, calcium $(\mathrm{Ca})$ and magnesium $(\mathrm{Mg})$. 
Distilled water suspension of each substrate was used to measure the $\mathrm{pH}$ after mechanical agitation for $30 \mathrm{~min}$ and filtration. $\mathrm{N}$ was analyzed by using the Kjeldhal method (Tandon, 1993). P, K, Mg and Ca were determined by using spectrometric methods (Olsen et al., 1954; Standford and English, 1949). TOC was determined according to the method used by Baize (1988).

The cassava agronomic parameters as the number of stems per cutting (NSC), the number of leaves per plant (NLP), the neck diameter of the stem (NDS), the stem length (SL), the length of leaves (LL), the scale of the plant (ScP) and the leaf width (LWi) were measured. The number of leaves per plant (NLP) was determined by multiplying the number of apexes per plant by the average number of leaves per apex (Daellenbach et al., 2005). Neck diameters of stems (NDS), stem lengths (SL) and leaf width were measured using the methodology described by Aniekwe et al. (2004) and Ambang et al. (2007). Yield and its attributes as the average number of tuberous roots per plant (NTRP), the mean weight of a tuberous root (WTRP), the weight of tuberous roots per plant (WTRP) were recorded. The yield of fresh roots per hectare $(\mathrm{Y})$ was calculated as followed:

$$
\text { Yield }=\frac{\text { NTRP } \times \text { WTRP }}{S} \times 10000
$$

NTRP = number of tuberous roots per plant;

WTRP = Average weight of a tuber per plant;

$\mathrm{S} \quad=$ Cultivated area

\section{Data Analysis}

A multivariate variance analysis (MVA) was performed with $\mathrm{R}$ software, version 3.1. The AMOVAs were supplemented by ANOVA tests when interactions were significant. When a significant difference was observed between the different factors, Least Significant Difference (LSD) multiple range-tests procedure were used to separate the means of the different treatments. Means were given as mean followed by standard deviation $(\mathrm{M} \pm \mathrm{SD})$. Significant differences were determined at $\mathrm{P} \leq 0.05$.

The principal component analysis (PCA) was performed using the software XLStat (2019) to test whether the type of soil treatment or fertilizer influenced yield and its attributes.

\section{Results}

Effect of Fertilizers on Growth Parameters of

\section{Cassava}

Table 1 encapsulates the chemical composition of the compost used in this study and the soil properties before the experiment. It appeared that each chemical parameter obtained with the compost was significantly higher in the cultivated soil.

The effect of fertilizers on cassava growth parameters is presented in Table 2. It appeared that the type of fertilizer influenced $(\mathrm{P}<0.001)$ the growth parameters of cassava. The number of stems per cutting differed significantly $(\mathrm{P}<0.05)$ from one type of fertilizer to another. The highest number of stems per cutting $(3.75 \pm 0.75)$ was obtained with NPK applied on the variety "Bonoua" and the lowest numbers were registered on the control plots with all the varieties which were similar statistically.

The length and the diameter of the stem depended on the variety of cassava and the type of fertilizer applied. The stem length varied from $67.61 \pm 45.22 \mathrm{~cm}$ to $128.72 \pm 68.59$ $\mathrm{cm}$ while the diameters varied from $13.01 \pm 5.68 \mathrm{~mm}$ to $23.29 \pm 13.14 \mathrm{~mm}$. The variety of cassava "Six mois" produced the longest stems and the "Bonoua" variety gave the shortest stems. However, the longest stems $(128.72 \mathrm{~cm})$ obtained with the variety "Six month" and the largest stems $(23.29 \mathrm{~mm})$ got with the variety "Bonoua" were registered when the mixture of NPK and compost was applied.

As for the number of leaves produced per stem and the size of the foliage, the plants in non-fertilized plots developed fewer leaves compared to plants in fertilized plots. The Bonoua variety with trichotomous branching developed more leaves with larger size whatever the fertilizer used compared to those obtained in the control. However, the highest number of leaves $(65.57 \pm 41.22)$ and the largest wingspan $(122.77 \pm 27.30 \mathrm{~cm})$ were observed with the "Bonoua" variety grown on plots where the mixture of compost -NPK was incorporated as fertilizer into the soil. The largest and the longest leaves were noted with the "Bonoua" and "Six mois" regardless of the type of fertilizer used. However, they were registered with the mixed compost and NPK.

\section{Effect of Type of Fertilizer on Yield Parameters of Cassava}

The yield of the different varieties of cassava in function of the type of fertilizer is represented on Figure 1. There was a significant variation in yield of the different varieties in this study. The highest yield (61.37 t/ha) was observed when the mixed compost-NPK was used to fertilize the variety "Bonoua". The lowest yield (12.51 t/ha) was obtained on the control plots with the variety "Yacé". Globally, for each type of variety of cassava, the highest yield was obtained when compost and NPK were mixed. The decreasing efficacy of fertilizers on cassava was CoMa-NPK, CoMa, NPK and control. Also, the variety "Bonoua" performed better with fertilizers than the other varieties whose decreasing order was as follow: Six mois $>$ Alleda agba $>$ yacé.

Table 1. Chemical composition of the compost and the soil

\begin{tabular}{l|cccccccc}
\hline \multirow{2}{*}{ Type of substrat } & \multirow{2}{*}{$\mathrm{pH}$} & \multicolumn{6}{c}{ Chemical characteristics $(\mathrm{g} / \mathrm{kg})$} & $\mathrm{M}$ \\
\cline { 2 - 7 } & & $\mathrm{C}$ & $\mathrm{N}$ & $\mathrm{P}$ & $\mathrm{K}$ & $\mathrm{Ca}$ & $\mathrm{Mg}$ & \\
\hline CoMa & $7.1^{\mathrm{a}}$ & $272.8^{\mathrm{a}}$ & $16.8^{\mathrm{a}}$ & $12.6^{\mathrm{a}}$ & $22.76^{\mathrm{a}}$ & $136.69^{\mathrm{a}}$ & $4.67^{\mathrm{a}}$ & $16.23^{\mathrm{a}}$ \\
Soil & $6.10^{\mathrm{b}}$ & $14.8^{\mathrm{b}}$ & $1.3^{\mathrm{b}}$ & $1.02^{\mathrm{b}}$ & $0.09^{\mathrm{b}}$ & $1.68^{\mathrm{b}}$ & $0.96^{\mathrm{b}}$ & $11^{\mathrm{b}}$ \\
$\mathrm{F}$ & 4.02 & 1.85 & 10.23 & 9.8 & 7.32 & 2.54 & 20.13 & 5.62 \\
$\mathrm{P}$ & $<0.001$ & $<0.001$ & $<0.001$ & $<0.001$ & $<0.001$ & $<0.001$ & $<0.001$ & $<0.001$ \\
\hline
\end{tabular}

CoMa: Compost from chicken manure, C: carbon, N: nitrogen, P: phosphorus, K: potassium, Ca: calcium, Mg: magnesium, C/N: ratio carbon-nitrogen; NB: Values followed by same letters in a column are not significantly different $(\mathrm{P}>0.05)$. 
Table 2. Effect of treatments and variety on cassava growth parameters

\begin{tabular}{|c|c|c|c|c|c|c|c|c|}
\hline $\mathrm{T}$ & V & NSC & LS (cm) & NLP & WLP (cm) & $\mathrm{LF}(\mathrm{cm})$ & $\mathrm{ScP}(\mathrm{cm})$ & NDS (mm) \\
\hline \multirow{4}{*}{$\mathrm{C}$} & $\mathrm{Yc}$ & $2.238 \pm 1.20^{\mathrm{b}}$ & $78.88 \pm 51.08^{\mathrm{i}}$ & $32.53 \pm 20.56^{\mathrm{k}}$ & $14.61 \pm 4.23^{c}$ & $14.73 \pm 4.75^{\mathrm{d}}$ & $71.27 \pm 33.58^{\mathrm{m}}$ & $13.16 \pm 5.95^{f}$ \\
\hline & $\mathrm{Aa}$ & $2.20 \pm 0.90^{\mathrm{b}}$ & $76.01 \pm 44.79 \mathrm{i}$ & $33.79 \pm 22.51^{\mathrm{j}}$ & $14.30 \pm 4.12^{c}$ & $14.32 \pm 4.51^{\mathrm{d}}$ & $75.00 \pm 32.20^{1}$ & \\
\hline & & $2.45 \pm 1.21^{\mathrm{b}}$ & $89.52 \pm 57.07^{\mathrm{h}}$ & $35.73 \pm 18.59^{\mathrm{i}}$ & $14.00 \pm 3.54^{\mathrm{c}}$ & $14.75 \pm 3.98^{d}$ & $83.68 \pm 25.87^{\mathrm{k}}$ & $13.45 \pm 6.25^{\mathrm{f}}$ \\
\hline & & $2.34 \pm 0.91^{\mathrm{b}}$ & $67.61 \pm 45.22^{j}$ & $38.00 \pm 25.43^{\mathrm{h}}$ & $14.53 \pm 4.51^{\mathrm{c}}$ & $13.88 \pm 4.57^{\mathrm{d}}$ & $85.41 \pm 30.74^{j}$ & $13.01 \pm 5.68^{\mathrm{f}}$ \\
\hline \multirow{4}{*}{ CoMa } & & $3.37 \pm 1.04^{\mathrm{a}}$ & $112.68 \pm 66.17^{d}$ & $46.20 \pm 26.04^{f}$ & $1.50 \pm 3.87^{b}$ & $15.29 \pm 4.21^{\mathrm{a}}$ & $100.65 \pm 33.98^{f}$ & $17.37 \pm 7.42^{\mathrm{c}}$ \\
\hline & & $3.23 \pm 0.90^{\mathrm{a}}$ & $115.75 \pm 63.80^{c}$ & $45.04 \pm 44.80^{\mathrm{f}}$ & $15.95 \pm 3.43^{b}$ & $15.18 \pm 4.18^{c}$ & $100.35 \pm 34.87^{\mathrm{f}}$ & $17.50 \pm 8.81^{\mathrm{c}}$ \\
\hline & $\mathrm{Sm}$ & $2.87 \pm 1.12^{\mathrm{a}}$ & $121.10 \pm 75.07^{\mathrm{b}}$ & $51.51 \pm 33.43^{\mathrm{d}}$ & $16.66 \pm 3.67^{\mathrm{a}}$ & $17.91 \pm 3.78^{\mathrm{a}}$ & $103.03 \pm 29.70^{\mathrm{e}}$ & $18.93 \pm 73.82^{b}$ \\
\hline & Bo & $3.62 \pm 0.81^{\mathrm{a}}$ & $108.05 \pm 60.69^{e}$ & $59.71 \pm 44.68^{b}$ & $16.75 \pm 4.05^{\mathrm{a}}$ & $17.10 \pm 4.21^{\mathrm{a}}$ & $109.95 \pm 32.09^{c}$ & $21.98 \pm 8.08^{\mathrm{a}}$ \\
\hline \multirow{4}{*}{ NPK } & & $3.09 \pm 0.9$ & $95.75 \pm$ & $40.96 \pm 22.2$ & 15.26 & $15.66 \pm 3$ & $27.70^{i}$ & $15.62 \pm 6.90^{\mathrm{e}}$ \\
\hline & $A$ & $3.42 \pm 0.88^{\mathrm{a}}$ & $96.58 \pm 59.23^{f}$ & $46.79 \pm 35.47^{f}$ & $15.38 \pm 4.14^{\mathrm{b}}$ & $15.14 \pm 4.7$ & $92.12 \pm 33.96^{\mathrm{i}}$ & $15.79 \pm 8.27^{\mathrm{e}}$ \\
\hline & & $3.51 \pm 0.92^{\mathrm{a}}$ & $111.14 \pm 72.27^{\mathrm{d}}$ & $48.95 \pm 31.57^{\mathrm{e}}$ & $16.58 \pm 4.03^{\mathrm{a}}$ & $16.39 \pm 3.64^{b}$ & $94.22 \pm 24.05^{\mathrm{h}}$ & $16.68 \pm 6.65^{\mathrm{d}}$ \\
\hline & & $3.75 \pm 0.75^{\mathrm{a}}$ & $91.96 \pm$ & $53.29 \pm 34.75^{\mathrm{c}}$ & $16.60 \pm 4.47^{\mathrm{a}}$ & $16.27 \pm 4.28^{b}$ & $98.17 \pm 29.32^{\mathrm{g}}$ & $17.81 \pm 6.89^{c}$ \\
\hline \multirow{4}{*}{$\begin{array}{l}\text { CoMa- } \\
\text { NPK }\end{array}$} & & $3.20 \pm 0.99^{a}$ & $116.84 \pm$ & $46.81 \pm 23.78^{f}$ & $15.32 \pm 4.19^{b}$ & $15.77 \pm 4.16^{\mathrm{c}}$ & $106.27 \pm 26.28^{d}$ & $17.02 \pm 6.61^{\mathrm{c}}$ \\
\hline & $\mathrm{Aa}$ & $3.38 \pm 1.21^{\mathrm{a}}$ & $117.72 \pm 59.04^{\mathrm{c}}$ & $46.70 \pm 32.93^{f}$ & $15.91 \pm 4.01^{\mathrm{b}}$ & $16.91 \pm 4.15^{b}$ & $104.32 \pm 32.81^{\mathrm{de}}$ & $4 \pm 8.15^{b}$ \\
\hline & & $3.47 \pm 1.16^{\mathrm{a}}$ & $128.72 \pm 68.59^{\mathrm{a}}$ & $52.01 \pm 31.56^{\mathrm{cd}}$ & $16.32 \pm 4.02^{\mathrm{a}}$ & $17.17 \pm 4.18^{\mathrm{a}}$ & $118.47 \pm 26.06^{\mathrm{b}}$ & $19.80 \pm 7.30^{\mathrm{b}}$ \\
\hline & & $3.07 \pm 1.03^{\mathrm{a}}$ & $112.93 \pm 46.258^{c}$ & $65.57 \pm 41.22^{\mathrm{a}}$ & $16.54 \pm 4.37^{\mathrm{a}}$ & $17.32 \pm 3.99^{\mathrm{a}}$ & $122.77 \pm 27.30^{\mathrm{a}}$ & $23.29 \pm 13.14^{\mathrm{a}}$ \\
\hline $\mathrm{F}$ & & 2.317 & 2.357 & 2.439 & & 3.16 & & 3.58 \\
\hline $\mathrm{P}$ & & $<0.01$ & $<0.01$ & $<0.001$ & $<0.001$ & $<0.001$ & $<0.001$ & $<0.001$ \\
\hline
\end{tabular}

T: Treatments; V: Varieties, NB: Values followed by same letters in a column are not significantly different (P $>0.05)$. NSC: Number of stems per cutting, LS: Length of stem, LWi: Leaf width, LL: Leaf length, NLP: Number of leaves per plant, ScP: Scale of the plant, NDS: Neck diameter of the stem, CoMa: Compost from chicken manure, NPK: Inorganic fertilizer, Yc: Yacé, Bo: Bonoua, Sm: six mois, Aa: Alleda agba, C: Control.

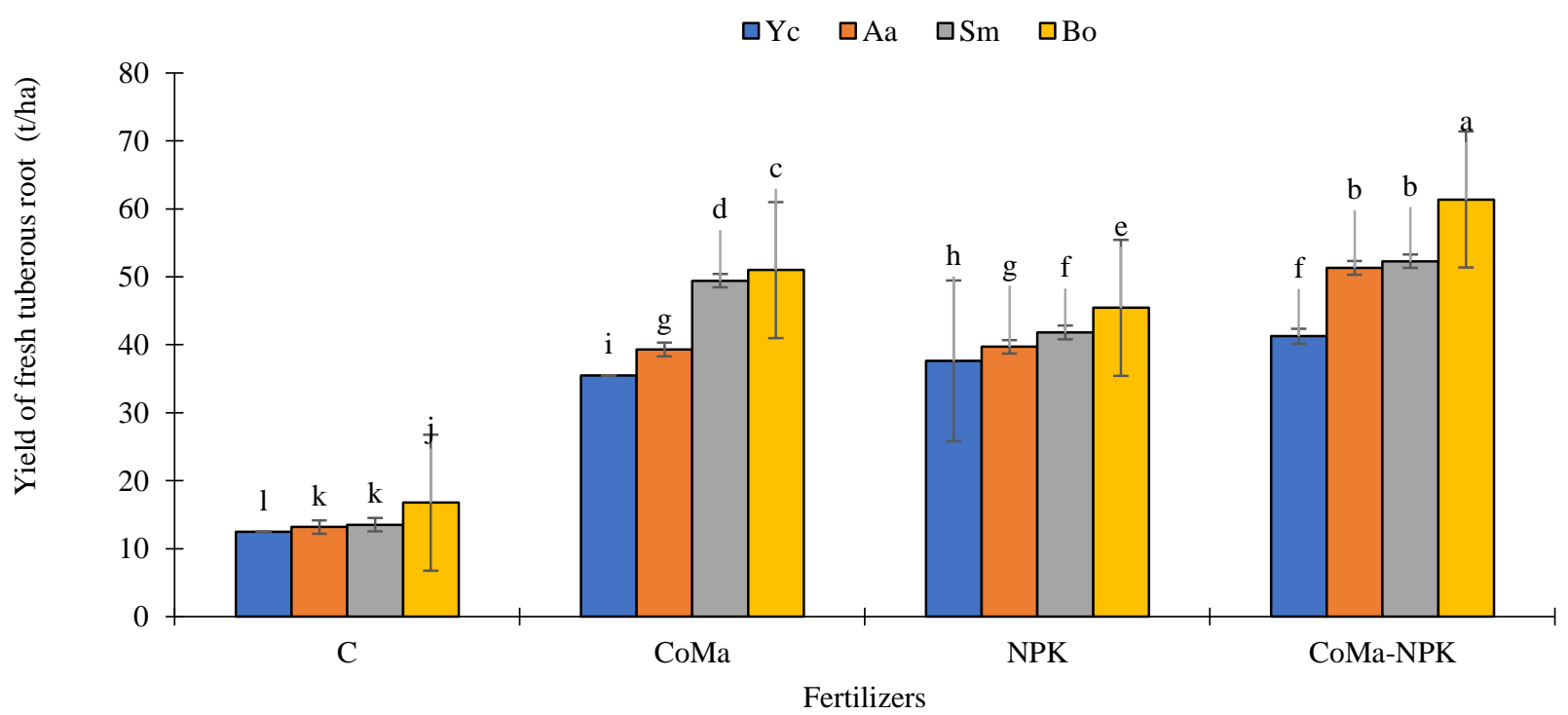

Figure 1. Effect of fertilizers on yield in function of cassava varieties. C: control, CoMa: compost from chicken manure, NPK: inorganic fertilizer, CoMa-NPK: mixed compost and NPK, Yc : yacé, Bo: Bonoua, Sm: six mois, Aa: Alleda agba

Yield attributes varied in function of the type of fertilizer and the variety of cassava (Table 3). Statistically, yield and its attributes of the different varieties differed significantly $(\mathrm{P}<0.001)$ in function of the type of fertilizer and variety.

The number of tuberous roots per plant varied from 3 to 6. According to the LSD test, the highest number of tuberous roots per plant $(5.83 \pm 0.73)$ was registered with the mixed compost-NPK spread on the variety "Bonoua" and the lowest $(3.13 \pm 0.68)$ was obtained with the variety "Six month" on the control plots. However, for each type of treatment, there was no significant difference between the number of tuberous roots per plant of the four varieties of cassava. Relatively to the weight of tuberous roots, it varied significantly in function of the variety for each type of fertilizer.

Except with the mixture of compost and NPK, the heaviest roots were measured with the varieties "Bonoua" and "Six mois" for all fertilizers. When the compost and NPK were mixed and spread, no significant variation was observed between the weight of roots. The weight of tuberous roots per plant was similar in the control plot despite the variety of cassava. With the compost and the inorganic fertilizer respectively, the weight of tuberous roots per plant varied significantly from one variety of cassava to another. However, for both fertilizers, the weight of tuberous roots per plant was similar for the varieties" Yacé" and "Alleda agba" on one hand and for 
"Bonoua" and "Six mois" on the other hand. Relatively to the mixture of compost and NPK, the highest weight of tuberous roots per plant was obtained with the variety "Bonoua" and the lowest was got with the other varieties which were similar statistically.

\section{Influence of The of Type of Fertilizer on Cassava Growth and Yield Parameters}

The principal component analysis (PCA) was performed to evaluate the relationships between the type of fertilizer (C, CoMa, NPK and CoMa-NPK) and cassava agronomic parameters (Y, NSC, ScP, LWi, LL, LS, NLP, NDS) as shown on Figure 2. The PCA1 and PCA2 explained respectively $76.97 \%$ and $9.50 \%$ of the total variances, either $86.47 \%$. The yield (Y), the number of stems per cutting (NSC), the length of main stem (LS), the leaf width (LW), leaf length (LL), the number of leaves (NLP), the scale of the plant (ScP), neck diameter of stem (NDS) were strongly correlated each to another. Except with the control, cassava agronomic parameters were also strongly affected positively by the type of soil treatment as the mixture of compost and inorganic fertilizer (CoMaNPK). The PCA clustered the different fertilizers in function of their efficacy on cassava growth. It appeared that inorganic fertilizer (NPK), compost (CoMa) and the mixture of both fertilizers (CoMa-NPK) had approximately similar effect on cassava agronomic parameters. In contrast to these latter, control was negatively correlated to yield parameters and to the other soil treatments methods.

Table 3. Yield attributes variation in function of the type of fertilizer and cassava varieties.

\begin{tabular}{|c|c|c|c|c|}
\hline \multirow{2}{*}{ Treatments } & \multirow{2}{*}{ Variety } & \multicolumn{3}{|c|}{ Performances parameters } \\
\hline & & NTRP & WTR $(\mathrm{kg})$ & WTRP (kg/plant) \\
\hline \multirow{4}{*}{$\mathrm{C}$} & Yc & $3.50 \pm 0.69^{\mathrm{d}}$ & $0.36 \pm 0.06^{\mathrm{e}}$ & $1.31 \pm 0.39^{\mathrm{g}}$ \\
\hline & Aa & $3.33 \pm 1.04^{\mathrm{d}}$ & $0.37 \pm 0.06^{\mathrm{e}}$ & $1.25 \pm 0.43^{\mathrm{g}}$ \\
\hline & $\mathrm{Sm}$ & $3.13 \pm 0.68^{\mathrm{d}}$ & $0.41 \pm 0.06^{\mathrm{d}}$ & $1.35 \pm 0.38^{\mathrm{g}}$ \\
\hline & Bo & $3.25 \pm 0.50^{\mathrm{d}}$ & $0.46 \pm 0.05^{\mathrm{d}}$ & $1.67 \pm 0.71^{\mathrm{g}}$ \\
\hline \multirow{4}{*}{$\mathrm{CoMu}$} & Yc & $4.12 \pm 0.69^{\mathrm{c}}$ & $0.78 \pm 0.12^{\mathrm{c}}$ & $3.55 \pm 0.88^{\mathrm{f}}$ \\
\hline & Aa & $4.12 \pm 0.77^{\mathrm{c}}$ & $0.86 \pm 0.12^{\mathrm{b}}$ & $3.93 \pm 0.81^{\mathrm{f}}$ \\
\hline & $\mathrm{Sm}$ & $4.05 \pm 0.62^{c}$ & $0.98 \pm 0.05^{\mathrm{a}}$ & $4.94 \pm 0.56^{\mathrm{b}}$ \\
\hline & Bo & $4.11 \pm 0.66^{\mathrm{c}}$ & $0.96 \pm 0.06^{\mathrm{a}}$ & $5.09 \pm 1.47^{\mathrm{b}}$ \\
\hline \multirow{4}{*}{ NPK } & $\mathrm{Yc}$ & $4.69 \pm 0.78^{b}$ & $0.80 \pm 0.20^{\mathrm{b}}$ & $3.76 \pm 1.18^{\mathrm{f}}$ \\
\hline & Aa & $4.38 \pm 0.83^{b}$ & $0.88 \pm 0.09^{\mathrm{b}}$ & $3.97 \pm 0.92^{\mathrm{f}}$ \\
\hline & $\mathrm{Sm}$ & $4.27 \pm 0.70^{\mathrm{b}}$ & $0.98 \pm 0.19^{\mathrm{a}}$ & $4.18 \pm 0.83^{\mathrm{e}}$ \\
\hline & Bo & $4.47 \pm 0.65^{\mathrm{b}}$ & $0.97 \pm 0.18^{\mathrm{a}}$ & $4.54 \pm 1.43^{\mathrm{e}}$ \\
\hline \multirow{4}{*}{ CoMa-NPK } & $\mathrm{Yc}$ & $4.97 \pm 0.81^{\mathrm{ab}}$ & $1.03 \pm 0.22^{\mathrm{a}}$ & $5.06 \pm 1.08^{b}$ \\
\hline & $\mathrm{Aa}$ & $5.30 \pm 0.92^{\mathrm{a}}$ & $0.96 \pm 0.13^{\mathrm{a}}$ & $5.13 \pm 0.91^{\mathrm{b}}$ \\
\hline & $\mathrm{Sm}$ & $5.44 \pm 0.84^{\mathrm{a}}$ & $0.93 \pm 0.09^{\mathrm{a}}$ & $5.22 \pm 1.17^{\mathrm{b}}$ \\
\hline & Bo & $5.83 \pm 0.73^{\mathrm{a}}$ & $1.03 \pm 0.14^{\mathrm{a}}$ & $6.13 \pm 1.37^{\mathrm{a}}$ \\
\hline $\mathrm{F}$ & & 2.68 & 6.92 & 3.428 \\
\hline $\mathrm{P}$ & & $<0.001$ & $<0.001$ & $<0.001$ \\
\hline
\end{tabular}

NTRP = number of tuberous roots per plant; WTRP = weight of a tuberous root; WTRP = weight of tuberous roots per plant; CoMa: chicken manure compost, NPK: inorganic fertilizer, Yc: yacé, Bo: Bonoua, Sm: six mois, Aa: Alleda agba; NB: Values followed by same letters in a column are not significantly different $(\mathrm{P}>0.05)$.

\section{Discussion}

Effect of Fertilizers on Growth Parameters, Yield and Its Attributes of Cassava

The different growth parameters of cassava evaluated in this study were the number of stems per cutting, stem length, neck diameter of stem, leaf number, leaf length and width, and scale of plant. These evaluated agronomic variables were strongly influenced by the variety and type of fertilizer applied to the soil. The agronomic parameters obtained with the compost and the inorganic fertilizer were higher than those got with the control. This result could be linked to the ability of compost and inorganic fertilizer to improve soil fertility, which in turn had increased the nutrients availability for plant growth. Similarly, Coulibaly et al. (2019) observed an increase in maize growth after applied compost and NPK. They explained their result by a higher content of plant nutrients in compost and inorganic fertilizer and the availability of the nutrients for the plant. It also appeared that, for each variety, the best developed growth parameters were observed with the mixed inorganic fertilizer and compost from chicken manure compared to

when they were brought separately. However, the highest agronomic performance was observed when compost and NPK were mixed and spread on the variety "Bonoua". The efficacy of the combined fertilizers could result in an associated effect of compost and NPK. In fact, organic fertilizers are known for their slow release of nutrients when applied on soil (Vern Grubinger, 2005) and therefore cannot meet crop requirements in a short time. Thus, the sole application of compost could not meet the usual intensity of agriculture production. Concerning inorganic fertilizers, they liberate nutrients as soon they are spread. These nutrients can be leached and won't be available to plants when they are needed. The efficacy of organic manure coupled with synthetic fertilizers has been confirmed to be a better approach to improve and sustain soil fertility and crop production than the sole application of mineral or organic manure by several authors (Kumar et al., 2017; Bandyopadhyay et al., 2010). Indeed, when they are combined, inorganic fertilizer might play a role of "priming effect" after what the action of organic fertilizer 
starts because of its slow action. In these conditions, the plant cannot miss nutrients during its growth. The results also showed that yield and its attributes differed in function of the varieties of cassava. The highest yield and the best yield attributes were obtained with the variety "Bonoua". These differences in yield and its attributes could be attributed to the initial characteristics of the varieties. The variety "Bonoua" might develop more roots that absorb sufficient nutrients for the development of the plant. Contrary to "Bonoua", the other varieties yacé, six mois, and Alleda agba might develop less roots and therefore assimilate little amount of nutrients that might influenced negatively their yield and attributes. Similarly, Olaiya and Salami (2017) found a significant difference in yield and its attributes while growing four yellow cassava varieties (IITA TMS 01/1368, IITA TMS 01/1371, IITA TMS01/1412 and IITA TMS 01/1593). The yields obtained in this study were significantly higher than the 9.33 t.ha $^{-1}$ got by Olaiya and Salami (2017). The observed difference could be linked to the variety of cassava and the type plot treatment.

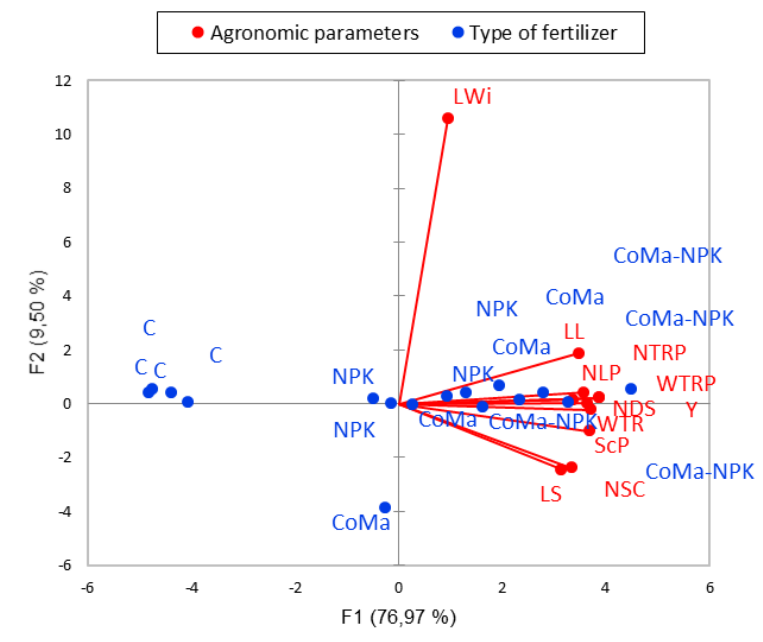

Figure 2. Influence of the of type of fertilizer on cassava growth and yield parameters.

(NTRP: number of tuberous roots per plant; WTR: weight of a tuberous root; WTRP: weight of tuberous roots per plant; LS: length of stem; ScP: scale of plant; LL: leave length; NLP: number of leave per plant; NDS: neck diameter of stem; LWi: leave width; Y: yield of fresh tuberous root per hectare, CoMa: chicken manure compost, NPK: inorganic fertilizer, Yc: yacé, Bo: bonoua, Sm: six mois, Aa: Alleda agba.)

\section{Correlation Between Fertilizers, Growth and Yield Parameters}

The principal component analysis (PCA) showed a positive correlation between cassava growth parameters and the type of fertilizer (compost, NPK, compost-NPK) on one hand and between the yield parameters and the type of fertilizer on the other hand. The positive correlation between the fertilizers as compost, NPK and the mix compost-NPK and yield parameters could be linked to their chemical composition that influenced yield and its attributes. Compost, NPK and the mixture of compost and NPK are known for containing plant nutrients that can improve plant growth, yield and its attributes (Mahmood et al., 2017; Olaiya and Salami, 2017; Coulibaly et al., 2019). It also appeared that the mixture compost-NPK was strongly correlated to cassava growth parameters, yield and its attributes compared to when they were used separately. Compost and NPK might be more efficient when they are combined than when they are separated. Similarly, Anas et al. (2019) found that organic manure coupled with inorganic fertilizer increased more rice growth and yield compared to when these fertilizers are used separately. The increase in cassava growth, yield and yield attributes under organic manure coupled with inorganic fertilizer treatment might be allied to the faster release of nutrients from mineral fertilizer increasing the photosynthetic capacity at early growth, while the slow and gradual release of nutrients from organic manure throughout the growing season enhanced photosynthetic ability, especially at the tuberous stage of roots. According to Mehasen et al. (2012), the co-applied use of manure and chemical fertilizer sustained soil fertility and improved nutrient uptake and plant growth.

The PCA showed a strong correlation between plant leaves and yield. The correlation between cassava leaves and yield could be explain by the ability of leaves anatomy to influence the photosynthetic capacity by changing the mesophyll thickness and increasing the space for chloroplasts at the cell surface necessary for the gas exchange (Oguchi et al., 2003). In fact, it has been shown that photosynthesis is the main driver of crop production by improving plant growth and biomass production (Khan et al., 2017). In the current study, compared with control, sole NPK application and compost application significantly enhanced cassava growth and yield parameters. This could be ascribed to the easier intake of nutrients from mineral fertilizer and compost fertilizer. In general, there was no significant difference between growth and yield parameters obtained with inorganic fertilizer and those got with organic fertilizer. The previous activity of microorganisms during the composting process by mineralizing the substrate could make the nutrients more available to plant. Our result in this study was contrary to that of Lazcano et al. (2013). Indeed, the authors showed that nutrients from inorganic fertilizers are more labile and available to plant than those from organic manures.

\section{Conclusion}

In this study, compost from chicken manure, inorganic fertilizer (NPK) and the mixture of both fertilizers increased cassava growth and yield compared to the control. There was no significant difference between growth parameters and yield parameters respectively obtained with the compost and with NPK. Compost coupled with inorganic fertilizer (NPK) gave the most developed plants and the highest yield. The different fertilizers were more efficient on the variety "Bonoua". Spreading the mixture of compost from chicken manure and inorganic fertilizer can lead to an optimal production of cassava precisely the variety "Bonoua" on a ferralitic soil in Côte d'Ivoire

\section{References}

Adjanohoun A. 2006. Détermination des doses d'azote, de phosphore et de potassium pour l'accroissement des rendements et la rentabilité du manioc au Sud du Bénin. Bulletin de la Recherche Agronomique du Bénin.9 p. 
Ambang Z, Akoa A, Bekolo N, Nantia J, Nyobe L, Ongono YSB 2007. Tolérance de quelques cultivars de manioc (Manihot esculenta Crantz) et de l'espèce sauvage (Manihot glaziovii) à la mosaïque virale africaine et à la cercosporiose du manioc. Tropicultura 25 (3): 140-145.

Anas I, Liang H, Aziz K, Shangqin W, Kashif A, Izhar A, Saif U, Fazal M, Quan Z, Ligeng J. 2019. Organic Manure Coupled with Inorganic Fertilizer: An Approach for the Sustainable Production of Rice by Improving Soil Properties and Nitrogen Use Efficiency. Agronomy 9: 1-20.

Aniekwe NL, Okereke OU, Anikwe MAN. 2004. Modulating effect of black plastic mulch on the environment, growth and yield of cassava in a derived savanna belt of Nigeria. Tropicultura 22 (4): 185-190.

Baize D. 1988. Guides des Analyses Courantes en Pédologie. INRA, Paris: Wiley Publishers. 192 p.

Bandyopadhyay K, Misra A, Ghosh P, Hati K. 2010. Effect of integrated use of farmyard manure and chemical fertilizers on soil physical properties and productivity of soybean. Soil Tillage Res. 110: 115-125.

Catello P, Palese AM, Celano G, Zaccardelli M. 2014. Effects of compost tea treatments on productivity of lettuce and kohlrabi systems under organic cropping management. Italian Journal of Agronomy 9: 153-156.

Coulibaly SS, Kouassi IK, Koffi KK, Zoro Bi IA. 2019. Effect of compost from different animal manures on maize (Zea mays) growth. Journal of Experimental Biology and Agricultural Science 7(2): $178-185$.

Daellenbach GC, Kerridge PC, Wolfe MS, Frossard E, Finckh MR 2005. Plant productivity in cassava-based mixed cropping systems in Colombian hillside farms. Agriculture, Ecosystems and Environment 105: 595-614.

Durand JR, Skubich M. 1982. Les lagunes ivoiriennes. Aquaculture 27: 211-250.

Ehab AI, Ahmed EA. 2015. Effect of Soil Amendments on Growth, Seed Yield and NPK Content of Bottle Gourd (Lagenaria siceraria) Grown in Clayey Soil. International Journal of Soil Science 10: 186-194.

Eke-Okoro ON, Dixon AGO. 2000. Influence of genotype $x$ environment on the productivity of improved cassava genotypes in humid ecozones of Nigeria. Nigerian Agricultural Journal 31: 125-133.

FAO. 1980. Les engrais et leurs applications. Food and Agricultural Organization of the United Nations. Rome (Italie): FAO, 51p.

FAO. 2017. Food and Agriculture Organization of the United Nations Statistics Division. Available online: http://faostat3.fao.org/browse/Q/QC/E (accessed on December 28, 2019).

Howeler RH, Oates CG, Allen AC. 2000. An assessment of the impact of cassava production and processing on environment and biodiversity. In: The Proceedings of the twelfth symposium of the ISTRC on the potential of root crops for food and industrial resources. Tuskuba, Japan pp53-54.

Jones WO. 1959. Manioc in Africa. Stanford University Press. Stanford Connecticut.

Khan A, Najeeb U, Wang L, Tan DKY, Yang G, Munsif F, Ali S, Hafeez A. 2017. Planting density and sowing date strongly influence growth and lint yield of cotton crops. Field Crops Research 209: 129-135.

Kumar U, Shahid DM, Tripathi R, Mohanty S, Kumar A, Bhattacharyya P, Lal B, Gautam P, Raja R, Panda BB. 2017. Variation of functional diversity of soil microbial community in sub-humid tropical rice-rice cropping system under longterm organic and inorganic fertilization. Ecological Indicators 73: 536-543.

Lazcano C, Gomez-Brandon M, Revilla P, Dominguez J. 2013. Short-term effects of organic and inorganic fertilizers on soil microbial community structure and function. Biology and Fertility of Soils 49: 723-733.
Liu E, Yan C, Mei X, Zhang Y, Fan T. 2013. Long-term effect of manure and fertilizer on soil organic carbon pools in dryland farming in northwest China. PLoS One 8: e56536.

Mahmood F, Khan I, Ashraf U, Shahzad T, Hussain S, Shahid M, Abid M, Ullah S. 2017. Effects of organic and inorganic manures on maize and their residual impact on soil physicochemical properties. Journal of Soil Science and Plant Nutrition 17 (1): 22-32.

Mehasen S, Gebaly SG, Seoudi O. 2012. Effectiveness of organic and inorganic fertilization in presence of some growth regulators on productivity and quality of egyptian cotton. Asian Journal of Biological Sciences 5: 171-182.

N'zué B, Zohouri PG, Sangaré A. 2013. Performances agronomiques de quelques variétés de manioc (Manihot esculenta crantz) dans trois zones agro climatiques de la Côte d'Ivoire. Agronomie Africaine 16 (2): 1 - 7

Natsheh B, Mousa S. 2014. Effect of Organic and Inorganic Fertilizers Application on Soil and Cucumber (Cucumis sativaL.) Plant Productivity. International Journal of Agriculture and Forestry 4: 166-170.

Nnadozie E, Anurnihe EC. 2003. Constraints of Small Farm holders to Cassava Production and Consumption. Agriculture: The Bed rock of an Enduring Democracy. Proceeding of the 37th Annual Conference of the Agricultural Society of Nigeria held at the University of Calabar. Calabar (Nigeria), pp106-110.

Nnodu EC, Ezukile TO, Asumugha GN. 2006. Cassava. In: Idem, U. U. A. and Showemimo, F. A. (eds.). Tuber and Fibre Crops of Nigeria: Principles of Production and Utilization 22: 2244.

Oguchi R, Hikosaka K, Hirose T. 2003. Does the photosynthetic light-acclimation need change in leaf anatomy? Plant, Cell and Environment 26: 505-512.

Ojeniyi SO, Ezekiel PO, Asawalam DO, Awo AO, Odedina SA, Odedina JN. 2009. Root growth and NPK status of cassava as influences by oil palm bunch ash. African Journal of Biotechnology 8 (18): 4407-4412.

Olaiya AO, Salami AO. 2017. Yield evaluation of yellow cassava varieties as affected by inorganic fertilizer in two agroecological zones of Nigeria. International Research Journal of Agricultural Science and Soil Science, 7(3): 46-50.

Olsen SR, Cole CV, Watanabe FS, Dean LA. 1954. Estimation of available phosphorus in soil by extraction with sodium bicarbonate. USDA Circular 939: 1-8.

Raffaillac JP. 1992. Enracinement de la bouture de manioc (Manihot esculenta Crantz) au cours des premières semaines de croissance. Agronomie Tropicale 46 (4): 273-281.

Scott GJ, Rosegrant MW, Ringler C. 2000. Global projections for root and tuber crops to the year 2020. Food Policy 25: 561597.

Standford D, English L. 1949. Use of flame photometer in rapid soil test of K and Ca. Agron J 4: 446-447.

Tandon HKS. 1993. Method of Analysis of Soils, Plant, Water and Fertilizer. New Delhi: Fertilizer Development and Consultation Organization. 143 p.

Toukourou AM, Carsky R. 2001. Réponse du manioc à l'azote, au phosphore et au potassium sur les terres de barre au sud du Bénin. In Actes de l'Atelier Scientifique, 12-13 décembre 2001, pp. 149-154.

Vern Grubinger. 2005. Managing nitrogen on organic farms. University of Vermont. http://www.uvm.edu/vtvegandberry /factsheets/managingNorganic.html.Accessed January 1, 2020.

Yao-Kouamé A, Alou KR. 2008). Propriétés du sol et domestication de Lippia multiflora (Verbenaceae) en Côte d'Ivoire. Agronomie Africaine 20: 97-107.

XLStat. 2019. https://www.xlstat.com/fr/articles/xlstatversion-2019$1-2$ 